\title{
CARNAVAL, UM TERRITÓRIO DE CRISE AS FORÇAS EM DEBATE NO CASO DO CRISTO MENDIGO (BEIJA-FLOR, 1989)
}

Fátima Costa de Lima (Udesc) Bruno Filippo (EACE)

Os debates políticos atravessam as pesquisas carnavalescas nas áreas da sociologia, da antropologia e da teoria da arte, da história europeia à brasileira e da Renascença às culturas contemporâneas, e invadem as Saturnais romanas tanto quanto os sambódromos atuais. A presença de estudos críticos acadêmicos em distintos temas como Rabelais, communitas e as escolas de samba do Rio de Janeiro nos mostra que as questões políticas distribuem os momentos de crise do carnaval que, paradoxalmente, parece fortalecer-se com elas. Este artigo desenha um breve contexto da crítica carnavalesca e analisa questões políticas de uma obra de arte em que forças antagônicas se encaram no concurso carioca das escolas de samba carnavalesco: a alegoria Cristo Mendigo do desfile "Ratos e urubus, larguem a minha fantasia!" (Beija-Flor, Joãozinho Trinta, 1989).

\section{CARNAVAL, CRÍTICA, DEBATE POLÍTICO, ALEGORIA.}

LIMA, Fátima Costa de e FILIPPO, Bruno. Carnaval, um território de crise: as forças em debate no caso do Cristo Mendigo (Beija-flor, 1989). Textos escolhidos de cultura e arte populares, Rio de Janeiro, v.9, n.1, p. 121-142, mai. 2012. 


\section{CARNIVAL, A TERRITORY OF CRISIS \\ THE FORCES INVOLVED IN THE "BEGGAR CHRIST" AFFAIR (BEIJA-FLOR, 1989)}

Fatima Costa de Lima (Udesc)

Bruno Filippo (EACE)

The political debates intertwine with the carnival research in the areas of sociology, anthropology and art theory, from European history to Brazilian one, and from the Renaissance to contemporary cultures, invading the Roman Saturnalia as much as the current "sambadromes". The presence of critical academic studies in various subjects such as Rabelais, communitas and the samba schools of Rio de Janeiro shows that the political issues distribute the periods of crisis in carnival while that, paradoxically, seems to gain strength from them. This paper draws a brief background of the carnival critics and analyzes politic issues of a work of art in which opposing forces face each other in the carnival samba school competition in Rio de Janeiro: the "Beggar Christ" (Beija-Flor, 1989).

CARNAVAL, CRITICISM, POLITICAL DEBATE, ALLEGORY.

LIMA, Fátima Costa de e FILIPPO, Bruno. Carnaval, um território de crise: as forças em debate no caso do Cristo Mendigo (Beija-flor, 1989). Textos escolhidos de cultura e arte populares, Rio de Janeiro, v.9, n.1, p. 121-142, mai. 2012. 
Na história há momentos felizes, mas não períodos felizes. Arnold Hauser (1993, p. 20)

A história do carnaval é atravessada por debates sobre a lei. Sejam ditadas pelo pensamento estético ou pelo jurídico, quer emanem da reflexão sociológica ou antropológica, as leis, como as normas, os manuais e os regulamentos, se estabelecem e estabelecem territórios de crise que negociam com a arte carnavalesca suas possibilidades de ação e mesmo de existência. Nesse contexto, o termo "crise" se refere à crítica que muitas vezes parece ser mais atuante do que a legislação; e aos conflitos que soem ser mais decisivos do que uma suposta harmonia e o equilíbrio sempre almejados, mas estranhamente ausentes no ambiente vivo do fenômeno carnavalesco. No caso do carnaval brasileiro e, mais especificamente, do carnaval carioca das escolas de samba, as questões políticas que distribuem os momentos de crise sempre estiveram em pauta. O que se modifica é o evento específico em que elas parecem sempre retornar para ser rediscutidas.

Este artigo se propõe a delinear um breve panorama da crítica carnavalesca. Para isso, atravessa três momentos. O primeiro percorre a crítica do carnaval que parte da pesquisa de Mikhail Bakhtin (2002), passa por sua retomada por Roberto Da Matta (1979) e é, por sua vez, criticada por outras pesquisas brasileiras mais recentes. Em segundo lugar, o artigo se concentra no carnaval das escolas de samba cariocas. Por fim, discute questões levantadas por um evento específico: a proibição da alegoria Cristo Mendigo no desfile de "Ratos e urubus, larguem a minha fantasia!" (Beija-Flor, Joãozinho Trinta, 1989).

\section{A CRÍTICA CARNAVALESCA}

Mikhail Bakhtin analisa a dualidade do mundo que contrapunha a cultura popular do riso - presente na sociedade medieval e no Renascimento e retratada nas obras de autores clássicos da literatura mundial, como Rabelais, Boccaccio, Cervantes e Shakespeare - e a cultura oficial, elevada e erudita, do Estado e da Igreja. A cultura do riso, jocosa e sarcástica ganhava a praça pública durante o carnaval quando prevalecia o reino utópico da liberdade, da universalidade e da igualdade, ao passo que, nas festas oficiais, que representam o Estado e a Igreja, as distinções hierárquicas eram mantidas.

Na cultura cômica, o plano abstrato, isto é, o sistema de crenças e ideias, se encontra, no âmbito dessa reflexão, rebaixado ao plano material e corporal, o que confere ao corpo caráter cósmico e universal. Esse mesmo corpo, quando associado às imagens da festança, da abundância, da alegria e da subversão, 
resulta no que Bakhtin classificou como "realismo grotesco" - a representação da realidade pelo que ela tem de disforme e desconexo, uma realidade que se mostra por inteiro nos momentos da festa carnavalesca. A partir de Bakhtin, a ideia de que no carnaval há inversão da ordem social - uma espécie de moratória do cotidiano - foi adotada pela pesquisa carnavalesca.

No Brasil, a reflexão já clássica do antropólogo Roberto Da Matta utiliza a teoria da inversão social para argumentar que o carnaval brasileiro é o momento em que se infundem valores igualitários numa sociedade hierárquica e autoritária. Maria Isaura Pereira de Queiroz (1992) foi a primeira a contestar a visão bakhtiniana do carnaval. Segundo a autora, essa visão seria em si um mito, ao passo que o carnaval vivido reflete - e não subverte - a ordem social vigente. A dificuldade de enquadrar o carnaval no paradigma da inversão social parece mais nítida quando pensamos em manifestações carnavalescas que se transformaram em espetáculo e entretenimento para as massas. $O$ pesquisador Felipe Ferreira (2005) questiona tal paradigma deslocando nossa atenção para o fato de que próprio carnaval renascentista foi patrocinado pelas grandes famílias italianas emergentes.

É no Renascimento que surge o modelo festivo transplantado para a colônia portuguesa setecentista e transfigurado num processo que se iniciou com os primeiros carros que desfilaram nos festejos de casamento do infante (CUNHA, 2001). Não eram, porém, carros carnavalescos: eles pertenciam antes à tradição europeia das celebrações de datas familiares comemorativas da nobreza e da aristocracia das cortes. Apareciam nas grandes encenações que perduravam ao longo de dias em cenários ambientados nos jardins particulares e nas ruas em que Margot Berthold localiza os trionfi:

Os átrios dos palácios, com seus arcos e galerias, as praças das cidades com suas arcadas e balcões, ofereciam uma oportunidade para que os convidados de honra assistissem aos trionfi literalmente colocados no alto, em cima - enquanto o cortejo passava num curso circundante. (...) O povo maravilhava-se com a pompa teatral de seus governantes, ou a pressentia, na medida em que conseguia captar algum vislumbre dela. Não raro, a aparentemente despreocupada magnificência representava o último e eufórico lampejo de um poder há muito debilitado (BERTHOLD, 2001, p. 296).

A historiadora alemã relata, entre outras, a festa preparada por Ludovico Sforza, o Mouro, para homenagear Isabella de Aragão que, em grande cerimônia realizada no Paço de Milão, se comprometeria com o sobrinho de Sforza. Uma grande exibição alegórica recebeu palco giratório e alegorias 
criados especialmente para a ocasião por Leonardo Da Vinci. Essa cena histórica é exemplar das relações políticas entre os artistas e as elites renascentistas.

São ocorrências similares que entram em cena quando os primeiros carros alegóricos apareceram na história da permanência da corte portuguesa no Brasil. Eles pertencem a um período demarcado pela hegemonia de uma arte aristocrática que servia à ostentação de status dos poderosos da cidade. Essa arte mais teatral do que carnavalesca revela que a noção que costuma frequentar a análise do carnaval do período do Antigo Regime é a da subversão popular decorrente da liberdade temporária, a mesma que Mikhail Bakhtin consagrou e que Peter Burke estende ao século XVIII.

Dessas pesquisas nos interessam dois pontos. Em primeiro lugar, a existência do carnaval, em suas origens históricas, parece depender diretamente da ação da Igreja (tema que retomaremos no final do artigo). Em segundo lugar, o caráter popular da festa decorre da estrita submissão das classes dominadas por um regime político estabelecido pela mesma Igreja e pelo Estado, na Renascença e no período barroco.

José Rivair Macedo (2000) contribui para estender nossa abordagem até a Idade Média, época que, segundo o historiador, reinventou o teatro. De modo paradoxal, as encenações medievais eram perseguidas pela Igreja ao mesmo tempo em que cediam suas formas para as práticas rituais eclesiásticas, e vice-versa, o que gerou uma espécie de promiscuidade artística mal suportada (mas igualmente mal controlada) pela dominação cristã. A partir do século XII, os dramas litúrgicos já encenados fora das igrejas conduziram ao surgimento dos gêneros teatrais invadidos por elementos populares e pagãos em espetáculos que, aos poucos, passariam a ser interpretados também por leigos, trovadores e menestréis: nos milagres, mistérios, fabliaux e jograis, os diabos cômicos povoavam autos, entreatos cômicos e farsas. O que interessa mais especificamente à crítica carnavalesca é que, em meio às modalidades que se estruturavam sobre temas religiosos impregnados com o espírito profano aparecem nessa época, nos registros históricos, as confrarias alegres:

Tais associações, irreverentes, satíricas e burlescas, participavam de procissões bizarras, promoviam farras e bebedeiras, em determinados períodos festivos, e envolviam-se em atividades condenadas pelas autoridades eclesiásticas. Elas possuíam estatuto próprio, elegiam um "rei" ou um "abade", adquiriam organização interna independente, desfrutando de privilégios especiais no período do ano em que se comemoravam as diversas festividades imbuídas de espírito carnavalesco (MACEDo, 2000, p. 224). 
Portanto, já nesse período podem ser observadas iniciativas de trabalho e organização das atividades carnavalescas em uma incipiente profissionalização das festas populares renascentistas. Segundo Peter Burke, "estava ocorrendo uma passagem gradual das formas mais espontâneas e participativas de entretenimento para espetáculos mais formalmente organizados e comercializados para espectadores, passagem esta que, evidentemente, prosseguiria por muito tempo depois de 1800" (BURKE, 1999, p. 271).

Em relação às escolas de samba, a insuficiência da teoria da inversão torna-se hoje quase óbvia. Todavia, tal insuficiência não encontra seus motivos somente no profissionalismo que rebate um dos corolários da teoria da inversão, o da liberdade experimentada no período carnavalesco. A baliza da lei parece ser intrínseca à própria existência do carnaval e, especialmente, a seu processo de institucionalização.

\section{A CRÍTICA DO CARNAVAL DAS ESCOLAS DE SAMBA}

No caso das escolas de samba brasileiras, o caráter apolíneo organizativo e de trabalho - do fenômeno originalmente carioca está presente desde seu surgimento e não só na forma das competições com regulamento, jurados, notas e quesitos: ela é tão antiga quanto as próprias escolas de samba.

O primeiro desfile foi uma disputa administrada pelo jornal Mundo Esportivo. Constituídas no final da década de 1920 pelas camadas populares da cidade, as escolas formavam um espaço comunitário de convivência entre pessoas de igual origem social. Esses grupos exibem um senso de pertencimento organizado pela lealdade local cujas regras, costumes e tradições transcendem o carnaval, resultando no processo artesanal e doméstico de confecção de fantasias, alegorias e instrumentos. Além do mais, enquanto a subvenção não chegava ou quando era insuficiente, a comunidade retirava dinheiro do próprio bolso para produzir a festa. O carnaval pode ser entendido, portanto, não como a moratória do cotidiano, mas como extensão da vida comunitária.

Embora as escolas de samba tenham dado continuidade aos desfiles de carros alegóricos das grandes sociedades - as agremiações ligadas às camadas mais altas da sociedade carioca cujo apogeu, na segunda metade do século XIX, conduzia às ruas os carros de crítica e de ideia (CUNHA, 2001) -, a estética das agremiações carnavalescas surgidas no século XX não pôde sustentar a tradição de jocosidade, sarcasmo e crítica política: às escolas de samba da década de 1930 dificilmente seria permitido tamanha liberdade de expressão. 
Como dependiam do reconhecimento do Estado, da imprensa e da sociedade, não Ihes convinha adotar postura abertamente crítica: nada de reivindicações, de enredos sobre conscientização de problemas sociais ou de denúncias à conjuntura social, enfim, nada que pudesse parecer subversão da ordem. Desse atrelamento político surgiu a necessidade das escolas de louvar com seu samba e sua arte a história oficial do país, suas riquezas, sua natureza, seus heróis, seu povo digno e trabalhador.

Os próprios sambistas se anteciparam à interferência do governo. Em 6 de setembro de 1934 foi fundada a primeira entidade representativa das escolas, a União das Escolas de Samba - UES, cujo estatuto foi elaborado pelos representantes das escolas. Esse documento previa que elas eram obrigadas a apresentar enredos nacionais, fato que desmonta a tese de que tal medida fora uma imposição do Estado Novo, implantado somente três anos depois. Em verdade, a proibição governamental aconteceu no governo Dutra - depois da redemocratização do país -, em razão da aproximação do Partido Comunista com as escolas de samba. Entre as reivindicações da UES apresentadas à prefeitura do então Distrito Federal estava a oficialização do desfile. A reivindicação foi aceita, e as escolas passaram a receber subvenção oficial a partir do ano seguinte. Na visão de vários estudiosos, se o reconhecimento oficial das escolas representava uma vitória, essa conquista custara-lhes, porém, preço muito alto: a subserviência ao Estado.

Queiroz cunhou a expressão "domesticação das massas urbanas" em alusão à oficialidade desejada e conquistada pelas escolas. Para a autora, vendo-se ameaçado pela manifestação cultural dos estratos inferiores, o Estado, representante das camadas superiores, tratou de colocá-los sob seu jugo. 0 resultado é que, embora a legalização das escolas de samba representasse uma "vitória das massas", também permitiu o reforço de seu controle pelas "camadas superiores". Todavia, a ênfase na atuação governamental negligencia o papel que os sambistas desempenharam no momento em que o poder público lhes abriu um espaço de reconhecimento: é-lhes negada pela crítica sua própria capacidade de negociação com o Estado. A obrigatoriedade dos enredos nacionais foi, enfim, uma demonstração de perspicácia que desmente tal visão, assim como a relação com o Partido Comunista. Paradoxalmente, alguns ativistas de movimentos sociais desprezam a ação dos sambistas daquele período, adotando a perspectiva da "domesticação das massas" e relegando ao segundo plano a topologia política de ação dos atores carnavalescos.

Embora não abandone por completo a visão de Queiroz, Monique Augras (1998) critica as análises maniqueístas que opõem as escolas de samba 
à ação estatal alternando movimentos dóceis com outros de confronto aberto numa paisagem de negociação em que as soluções buscam responder aos anseios dos sambistas tanto quanto aos de seus patrocinadores: o Estado, o turismo e a contravenção. A pesquisadora indaga a tendência da crítica dos anos 80 de reforçar a cena da "cidadania" em textos em que o mundo do samba representaria a cultura popular antagônica ao Estado oferecendo barreiras à repressão governamental: segundo Augras, já nos anos 30 a UES se apresentava ao contexto eleitoreiro como entidade capaz de aglutinar os votos populares a serviço deste ou daquele político.

A referência aos anos 80 - além de situar historicamente trabalhos acadêmicos como o de Queiroz - poderia também conduzir nosso olhar para as experiências de escolas como a Caprichosos de Pilares e a São Clemente. Não se enquadrando no perfil das "superescolas", elas desenvolveram enredos sarcásticos com alusão à política brasileira e à profissionalização do samba, o que acabou por reforçar perante a opinião pública a ideia de que o carnaval é momento propício para a manifestação da crítica social. A conjuntura de fim da ditadura trouxe expectativas quanto à redemocratização e à mobilização popular abrindo um espaço de crítica tanto para os estudiosos quanto para as escolas. Estas últimas, porém, acabaram por protagonizar apenas algumas daquelas exceções que confirmam a regra: mesmo com o fim do ciclo de enredos ufanistas da década de 1970, as escolas nunca abandonaram totalmente esse tipo de enredo, nem depois de abolida, em 1997 a obrigatoriedade de temas nacionais.

Os exemplos dos últimos anos são ainda mais eloquentes: no carnaval de 2003, a última alegoria da Beija-Flor trazia uma escultura do presidente Lula num enredo que, falando da fome, fazia alusão ao programa Fome Zero do governo recém-empossado. Em 2005, a Portela levou à passarela as oito metas da Organização das Nações Unidas - ONU para este milênio, tema que, embora não ufanista, decorre da visão politicamente correta que, nos enredos, passou a representar o status quo. Em 2006, a mesma Portela homenageou a garra e a luta do mestiço povo brasileiro. Em 2008, as escolas do Grupo Especial criaram enredos em homenagem ao bicentenário da chegada da família real portuguesa ao Brasil.

"Sonhar com rei dá leão", enredo do desfile da Beija-Flor em 1976, presta homenagem ao jogo do bicho. Esse enredo poderia, à época, ter ilustrado a teoria da inversão de Bakhtin ao tomar como tema um jogo com muito sucesso entre as camadas populares e que se encontra no território da contravenção. Por outro lado, por tratar de atividades proibidas por lei, poderia ter sido 
contestado pelo Estado. Mas nada disso aconteceu: foi um desfile posterior da Beija-Flor - o de 1989, protagonizado pelo Cristo Mendigo -, que teve que lidar de frente com as questões de proibição, justiça, contravenção e inversão do mundo. Essa alegoria centralizou as questões políticas do carnaval das escolas de samba justamente quando findava a década de inversão da crítica, como propõe Augras.

A partir desse momento, nos empenharemos - ainda que de modo breve e necessariamente incompleto - por desdobrar os sentidos de um objeto da arte carnavalesca que concentrou em si uma crise política que sintetiza dialeticamente séculos de história mundial e décadas de debate brasileiro sobre o que pode e o que não pode acontecer no carnaval.

Observado de perto, o Cristo Mendigo constitui-se como objeto em crise: mais do que à admiração do objeto cuja beleza das formas e harmonia das cores justificaria uma nota 10 de um suposto jurado de alegoria e adereços num concurso de escolas de samba, essa alegoria parece, antes, oferecer-se abertamente e com muito boa vontade à crítica. Antes de nos aproximarmos, porém, tracemos seu entorno: o próprio ano em que ele surgiu se mostraria um ano de muitas e fortes crises. Escolhemos, como exemplo, apenas duas delas, que faremos aqui representar-se pela análise de suas imagens. Embora poucas em número, elas constituem verdadeiros marcos de nossa contemporaneidade.

1989 foi generoso em imagens políticas. Em meados do ano, o exército nacional chinês reprimiu violentamente a massa que protestava contra o regime na Praça da Paz Celestial (Tiananmen), em Pequim. O acontecimento se representa na fotografia de 5 de junho em que um desconhecido fez parar a fila de tanques blindados ao colocar-se à frente dela, criando uma imagem que simboliza a determinação do indivíduo anônimo em opor-se às forças do Estado poderoso e repressor. Contudo, o pequeno David contemporâneo que enfrentou o desfile das alegorias bélicas com sua fantasia de esperança sumiu: a imagem que comoveu o mundo é a de um desconhecido que desapareceu diante de nossos olhos.

Em 9 de novembro do mesmo ano, a massa alemã comemorou a queda do Muro de Berlim. Construído na madrugada de 13 de agosto de 1961, a barreira que dividiu ao meio a Alemanha por quase três décadas concentrava, simultaneamente, os efeitos reais e simbólicos da penalização do país nazista após a guerra que ele mesmo promoveu e perdeu.

Num certo sentido, o Cristo Mendigo parece antecipar o impacto das imagens das ruínas do final da década de 1980: a alegoria desfilou na alvorada 
de 7 de fevereiro de 1989, ${ }^{1}$ antes dos tanques chineses, numa festa que antecedeu as comemorações da unificação da cidade de Berlim.

Nossa proposta é, a partir daqui, analisar o evento do Cristo Mendigo sob duas perspectivas políticas distintas. Na primeira, a alegoria se relaciona ao enredo que o carnavalesco Joãozinho Trinta tratou como denúncia política, fazendo um percurso externo à alegoria para investigar as relações que ela trava com sua própria sociedade. Na segunda, a política interna da escola será abordada através do debate acerca da autoria da alegoria.

\section{O CRISTO MENDIGO COMO DENÚNCIA POLÍTICA}

O carro alegórico do Cristo Mendigo - um carro modificado nas vésperas do desfile porque seu projeto original foi proibido de última hora pela justiça carioca respondendo à solicitação da Cúria Metropolitana do Rio de Janeiro foi o abre-alas de 1989 da escola de samba Beija-Flor de Nilópolis na Passarela do Samba Darcy Ribeiro. O carro alegórico que passou imediatamente depois do Cristo Mendigo foi o Carro-convite, que convocava ao carnaval a escória e o populacho das ruas. Depois, passou o Carro Lixo do Luxo, fechando o primeiro setor do desfile.

Numa escola de samba, o desfile espelha o enredo através de setores compostos por alas, carros alegóricos e outras figuras carnavalescas (como o casal de mestre-sala e porta-bandeira e a comissão de frente). Ele deve expressar ao público do sambódromo ou da televisão (no caso do grupo principal do concurso carioca) as formas visuais, plásticas, cênicas, coreográficas e musicais daquilo que, no enredo, é pura literatura. De Joãozinho Trinta, o enredo de 1989 denuncia aqueles que enriquecem de modo ilícito conduzindo o Brasil "para o caos. Para um outro Período das Trevas. O miserável da Rua pode não ter consciência da história, mas ele está repetindo a História. Ele é o mesmo ser humano degradado pelo Poder." (TRINTA in CUNHA JR., 2006, p. 124) Na alegoria dos vencidos de Joãozinho Trinta, a falta de consciência é responsável pela repetição dos erros da história. A alegoria Lixo do Luxo, por sua vez, figura uma corte medieval. Nesse carro se lê "Sou na vida um mendigo"; e, nas laterais da alegoria, faixas verticais complementam os dizeres anteriores com a frase: "Na avenida eu sou rei". Todo o conjunto faz reverência ao mendigo que se torna rei e referência ao carnaval renascentista e barroco investigado por Bakhtin (2002).

Seguiam-se o Carro da Tenebrosa, representante do luxo da Igreja com os quatro cavaleiros do Apocalipse; o lixo da guerra, conteúdo do Carro dos Loucos; o Carro da Sauna Romana denuncia a promiscuidade e a libertinagem 
sexual; o Carro da Imprensa ataca o lixo produzido pela mídia sob a forma de notícias; o lixo da política se representa no Carro Oba Oba no Planalto; o Carro dos Brinquedos critica os brinquedos com alto valor comercial ou demonstrativos de agressão e violência; o Carro da Xepa traz a sobra das feiras que alimentam os mendigos; e o Carro do Chafariz da Cinelândia, a penúltima alegoria do desfile, purifica os mendigos e o povo da rua. Fechando o cortejo, um carro de bombeiros real espalhava água para todo lado. Joãozinho Trinta, o carnavalesco, empunhou ele mesmo a mangueira que refrescou o público da Avenida Marquês de Sapucaí.

Composta em parte por esses carros alegóricos, a visualidade da BeijaFlor mostrava o lixo sagrado, aquele que a população profanadora das ruas soube roubar para fazê-lo retornar ao convívio dos homens (AUGRAS, 2007) na alegoria proibida. Ela e seu séquito da Ala de Mendigos ocupavam o primeiro setor que se mesclava, no decorrer do desfile, às representações do luxo, o pseudosagrado produzido pela corrupção (DEBORD, 1997) que ocupa o restante do desfile. O jogo dialético entre o lixo e o luxo produziu a crítica social que percorreu a totalidade do desfile. Nas palavras de Joãozinho Trinta:

Eu quis fazer uma denúncia porque, quando cheguei ao Rio de Janeiro, em 1951, Copacabana era um local de encantamento. E, de repente, estava suja, uma feira de peixe, me revoltei ao ver tanta família dormindo debaixo dos viadutos. [Irônico] E se os críticos diziam que eu não retratava a realidade brasileira... (...) Sempre respondi que ser pobre num Brasil tão farto, tão rico, é que é irreal. Os ratos e urubus eram os que me criticavam. (...) Incomodava porque eu sabia o que era miséria. Lá no morro, percebi a chegada do tóxico, da violência, das crianças abandonadas. Nitidamente, a causa da decadência do Rio de Janeiro tinha sido o êxodo provocado pelo abandono do campo, criando esses bolsões de miséria que são as favelas, as palafitas, as baixadas (TRINTA in PETTA, 1998, p. 33).

Morar no morro lhe deu, pois, a perspectiva para criticar a decadência da paisagem urbana do Rio de Janeiro. Sua crítica faz lembrar algumas descrições da Paris do século XIX, a cidade cuja reforma urbana inspirou Walter Benjamin (1989; 2007) a preconizar a decadência do projeto moderno já em seus primórdios (e que seria mimetizado na proposta de urbanização da cidade do Rio de Janeiro nos anos 20). Essas imagens acessíveis somente a quem viveu na periferia e no morro tornaram-se, pois, o ponto de partida do enredo "Ratos e urubus, larguem a minha fantasia!"

Por outro lado, o enredo se refere também aos "ratos e urubus" que criticavam a arte do carnavalesco: quando viu questionada sua estética do luxo, 
Joãozinho resolveu fazer o desfile do lixo. Porém, luxo e lixo não se relacionam através de uma dura e restrita oposição: visto do início, o desfile revela aos poucos uma visualidade luxuosa que serve de pano de fundo para as imagens do lixo. Depois, as operações visuais entre ambos se acentuam para fazer girar a dialética de uma estranha Gestalt que alterna montes de luxo e restos de lixo: Joãozinho faz corresponderem, no enredo e no desfile, na palavra e no visual, o luxo artístico com a decadência e o lixo com a miséria. A totalidade da representação, porém, é claramente assimétrica: o lixo ocupa talvez menos espaço, mas possui mais peso: é em torno dele que a arte carnavalesca gravita.

O enredo "Ratos e urubus larguem a minha fantasia!" cria, pois, um movimento pendular entre luxo e lixo. Polarizando esse trânsito, Milton Cunha Júnior (2006) desdobra em "inferno" e "paraíso" dez enredos de Joãozinho Trinta, entre eles o do carnaval do Cristo Mendigo. O pesquisador e carnavalesco divide as imagens dos enredos: algumas habitam o paraíso-otimismo e outras o inferno-pessimismo.

Nas 11 páginas dedicadas ao paraíso, o desfile de 1989 é citado apenas três vezes. Na primeira se destaca o mapa do Brasil em forma de um grande coração que acolhe amorosamente seus habitantes. Mas, rapidamente se transforma em protesto contra o desequilíbrio social de

um país que tem sua geografia na forma de um grande coração. Invertido, desequilibrado, de cabeça para baixo, porém, mostrará contornos de uma enorme bunda. E uma bunda do tamanho do Brasil tem muita sujeira insistindo para ser expelida. Somente as bacias do Amazonas e do Prata poderão lavar tantos excrementos (TRINTA, apud CUNHA JR. 2006, p. 120)

Coração invertido em bunda, o mapa de Trinta contrapõe ao disegno de um país-afeto os elementos geográficos transfigurados em fluidos corpóreos enquanto, por outro lado, ele incita a natureza a realizar o trabalho de purificação da sujeira política. Joãozinho sugere que a tarefa heroica da natureza deve ceder lugar à energia do povo quando se tornar consciente. Recorrendo a uma imagem do Hino Nacional brasileiro, o enredo segue afirmando que "somos ainda o Gigante que acordou e está levando tanta porrada, está sendo tão sacaneado que de repente fica inerte. É preciso alfinetá-lo para que comece a reagir. E é obrigação de todos nós participar deste trabalho" (idem). Transformando a pista carnavalesca em tribuna, a Beija-Flor parece retomar as palavras de Vsevolod Meyerhold (1874-1940), diretor russo cujo teatrotribuno não se deixou intimidar pelo Estado totalitário de Stalin. Como afirmou 
Meyerhold, "É preciso falar. Não basta limitar-se a exemplos, e sim falar como se deve" (MEYERHOLD, 1994, p. 312). ${ }^{2}$

Mas não é exatamente da fala que é feita a arte de um carnavalesco: embora tenha adquirido a fama de falar demais Joãozinho, através da formulação da antinomia imagética coração-bunda, protesta com seu trabalho, seu "ofício":

Cada um deve agir à sua maneira. No nosso caso, nós sabemos fazer carnaval, é o nosso ofício. Que seja através dele, então, que a gente proteste. Esperamos assim contribuir para despertar o Gigante que somos nós. Então lançamos o grito: "Ratos e urubus, larguem a minha fantasia". Será o lixo do luxo. Será o luxo do lixo. (TRINTA apud CUNHA JR. 2006, p. 120-121)

A segunda imagem otimista desse enredo é a do bom brasileiro representado pelo povo da rua, o mendigo com alma pura como a de Buda, "uma clara idealização do homem simples, pobre, abandonado" (CUNHA JR., 2006, p. 65). E, por último, Cunha Jr. destaca a imagem do carnaval carioca como uma "festa da redenção, maior espetáculo da terra em grandeza, criatividade e vibração" (p. 67).

Se há pouco espaço para "Ratos e urubus, larguem a minha fantasia!" no paraíso, esse enredo domina o inferno: do espaço de cinco páginas dedicadas às questões pessimistas, metade lhe é reservada. Além do mais, deve-se notar que os outros seis enredos selecionados para compor o capítulo demoníaco pertencem a desfiles posteriores a 1989, o que indica uma espécie de tradição de conteúdo crítico inaugurada pelo carnavalesco com aquele desfile: a da temática social. Desonestidade, desrespeito, inflação, falcatrua, miséria, drogas e prostituição; sucateamento da cultura, da tradição e da identidade; desmandos e lideranças políticas falsas ou ausentes; corrupção, sem-vergonhice e politicagem; criminalidade e violência em consequência da prepotência do poder; loucura, fome e opressão: são esses alguns dos assuntos com que o crítico Joãozinho Trinta se esforça por iluminar as mentes presentes na avenida.

Em "Todo mundo nasceu nu" (1990), Joãozinho costura um vínculo entre o jogo do bicho e o carnaval que, para ele, oferece a imagem mais positiva do Brasil. Enredo do ano seguinte, "Alice no Brasil das Maravilhas" (1991) chama a atenção para a infância abandonada e, na sequência, "Há um ponto de luz na imensidão" (1993) comenta a violência urbana. "Tereza de Benguela, uma rainha negra no Pantanal" (1994) - criado pelo agora carnavalesco da Viradouro depois de um ano de ausência para recuperação de uma isquemia - identifica na mulher o sofrimento pela política que empesta o país. Em “Orfeu, o negro do 
carnaval" (1998) o cenário dos morros e das favelas torna-se palco de tiroteios e balas perdidas. Por fim, em seu primeiro carnaval na Grande Rio, Joãozinho Trinta prestou homenagem ao poeta andarilho "Gentileza X, o Profeta do Fogo" com enredo que aponta o prejuízo, para a arte e para a poesia, do avanço tecnológico desmesurado e sem limites.

Os enredos de denúncia mostram que subsiste, no carnavalesco, o cidadão preocupado com as questões sociais brasileiras. O carnaval de Trinta estabelece correspondência, nem sempre bem recebida, entre a diversão e os temas sérios de um país em que a política e a oficialidade ostentam a pior imagem possível. Desse modo ele sobrepõe ao aspecto festivo um pensamento crítico que seus próprios críticos se recusam a perceber em seu carnaval.

Desse modo, eles furtam ao festejo uma de suas faces mais efetivas - como produtividade e como efeito - que acaba por tornar-se aguda na figura do Cristo Mendigo: a imagem do carnaval político.

\section{O CRISTO MENDIGO COMO OBRA DO COLETIVO}

A questão da autoria do Cristo Mendigo é assunto que sempre esteve em debate e ao qual nos permitimos uma pequena contribuição expressa, por sua vez, em uma imagem alegórica (MURICY, 1999). Com a expressão "imagem alegórica" nos referimos àquelas imagens de pensamento em que Walter Benjamin (2004) faz emergirem sentidos políticos contestatórios e revolucionários (porque diferem de uma visão de cunho classicista e totalitário) na expressão e na manifestação artística ou literária.

Tracemos nossa imagem: se o pré-natal da construção da alegoria do Cristo Mendigo no barracão da Beija-Flor foi tranquilo, o parto foi de risco. Por um lado, a imagem original do Cristo Redentor foi coberta com um plástico negro por sua mãe amorosa, o artista carnavalesco. Por outro, dom Eugênio Salles - o arcebispo da Cúria Metropolitana do Rio de Janeiro que solicitou a proibição da alegoria - pode ser corresponsabilizado por sua forma final, pois ela não existiria se a original não fosse por ele proibida. Como progenitor da alegoria, ele se demonstrou pai problemático que, numa espécie de crise de depressão pré-parto, tentou eliminar o feto ainda na barriga da mãe.

Sob a inspiração dessa imagem dialética, já de partida o Cristo Mendigo não pertence somente a Joãozinho Trinta. Porém, o carnavalesco-mãe, maravilhado com o filho disforme, uniu-se ao coro formado por público e foliões no sambódromo para abraçar os braços abertos da alegoria, ainda que esse estranho natimorto paradoxalmente ressuscitado que saiu do barracão da Beija- 
Flor não fosse mais a cópia do Cristo Redentor que deveria desfilar, se não fosse proibida, em trapos brancos. Gestado alvo, ele nasceu preto.

A imagem que o livro A origem do drama trágico alemão (BENJAMIN, 2004a) apresenta da história é de sofrimento e malogro. Essa percepção transparece tanto na noção de história dos vencidos a ser resgatada do esquecimento a que foi relegada pela história dos vencedores (BENJAMIN, 1994; LöWY, 2005) quanto no fragmento do Trauerspielbuch ${ }^{3}$ em que a história surge relacionada diretamente ao conceito de alegoria:

na alegoria o observador tem diante de si a facies hippocratica da história como paisagem primordial petrificada. A história, com tudo aquilo que desde o início tem em si de extemporâneo, de sofrimento e de malogrado, ganha expressão na imagem de um rosto - melhor, de uma caveira. E se é verdade que a esta falta toda a liberdade simbólica da expressão, toda a harmonia clássica, tudo o que é humano - apesar disso, nessa figura extrema da dependência da natureza exprime-se de forma significativa, e sob a forma do enigma, não apenas a natureza da existência humana em geral, mas também a historicidade biográfica do indivíduo. Está aqui o cerne da contemplação de tipo alegórico, da exposição barroca e mundana da história como via crucis do mundo: significativa, ela é-o apenas nas estações da sua decadência.(BENJAMIN, 2004a, p. 180-181).

Essa ideia, ou imagem, parece ecoar na opacidade do Cristo carnavalesco: a "paisagem petrificada" em que o filósofo alemão enquadra a história se espelha na forma compacta e sem o brilho costumeiro das alegorias carnavalescas. Como uma "caveira" do Cristo Mendigo original, a alegoria que desfilou - embora, de certa forma, também tenha ressuscitado como ressuscitou o Cristo cristão - não mais parecia representar o corpo redivivo do filho de Deus na Terra. Contudo, como manifestação da privação da liberdade de expressão artística, a obra responde à ideia de traição que consta do plano de Joãozinho Trinta quando, no enredo, se remete à Igreja.

Ela já se achava representada no projeto original do carnavalesco. A alcunha de "Tenebrosa" Ihe foi dada antes da proibição da alegoria original Cristo Mendigo, assim como também o "lixo das igrejas" (TRINTA in CUNHA JR., 2006, p. 124) e dos "pedintes das portas" (idem) chamados a se "fantasiar com os restos do luxo (...) Toda a riqueza adquirida com a fé e a promessa da salvação das almas" (ibidem) - são expressões que constam do enredo do carnavalesco. No entanto, quando a Cúria carioca interveio no processo de criação da alegoria, ela fez reviver o terror da Inquisição barroca na atualidade 
carnavalesca. É desse modo que a Igreja pode, então, ser considerada a coautora da alegoria. À revelia, mas ainda assim coautora.

Surpreendentemente, nada disso é novidade: segundo a pesquisadora norte-americana Barbara Ehrenreich, foi a própria Igreja que, às vésperas da Renascença, "inventou o carnaval", pois

Expulsas do domínio físico da igreja, a dança, a bebedeira e outras brincadeiras que tanto irritavam as autoridades eclesiásticas se converteram em festividades que encheram o calendário do final dos tempos medievais e início da Igreja moderna, em dias santos, logo antes da quaresma, e em uma série de outras ocasiões ao longo do ano. Em sua batalha contra a tensão extática dentro do cristianismo, a Igreja, sem dúvida inadvertidamente, inventou o Carnaval (EHRENREICH, 2010, p. 100).

Outra questão de autoria surge no depoimento em que Laíla - o coordenador do carnaval da Beija-Flor em 1989 (e também atual) - relata como o Cristo Mendigo ganhou seu manto preto:

Nós estávamos em Copacabana, no apartamento antigo do Anísio, quando ligaram para lá [dizendo] que o oficial de justiça tinha chegado no barracão, proibindo do Cristo sair. Saímos da casa do Anísio, entramos, viemos pelo túnel, chegou lá dentro do túnel eu falei: "Não se preocupe: vamos cobrir e vamos criar a frase: Mesmo proibido, olhai por nós." Saímos com essa ideia fixa. O Anísio queria: "vamos botar o João acorrentado no Cristo..."4

Laíla segue narrando que, ao entrar no barracão da Beija-Flor juntamente com Aníz Abrão David - o “Anísio", então presidente da escola - encontrou

um tumulto terrível, o João gritando: "Ninguém bota a mão no meu Cristo!". Chamamos ele em particular...: "Tem duas ideias: tem uma de você vir acorrentado no Cristo, que é a ideia do Anísio; e a outra minha do Cristo vir coberto, com essa frase." [Joãozinho Trinta] "Não quero saber de nada disso!", foi a posição dele de imediato. Sumiu, foi lá dentro. Quando voltou: "Reúne a imprensa!" Reuniu a imprensa e falou: "Tive uma ideia: vou cobrir e vou botar essa frase assim, assim e assim..." (idem)

No audiovisual em que está gravado o depoimento, se percebe que Laíla destila um profundo sentimento de desgosto por ter sido traído pela omissão do amigo Joãozinho Trinta: "Fiquei estarrecido, mas fiquei na minha. Eu gostava dele, gosto dele, não falei nada. (...) mas eu posso bater no peito [bate no peito] que é minha. (...) ele saiu pela tangente, mas ele sabe que é verdade" (ibidem). É dessa forma que Laíla puxa para si o foco da luz que revela a autoria 
do Cristo Mendigo. Mas, será essa uma disputa legítima no âmbito da arte contemporânea?

O teórico da arte italiano Mario Perniola afirma que a arte atual viu reduzida a importância do sujeito criador. O filósofo italiano pressente no artista a figura de alguém que observa atentamente o mundo e está sempre alerta para sentir e agir a partir de uma "concepção de beleza do tipo estratégico, aguda e pungente" (PERNIOLA, 2000, p. 42). Essa noção - originalmente formulada no século XVII pelo pensador jesuíta espanhol Baltasar Gracián (1601-1658) - serve para explicar como a atuação do artista barroco conduz a um envolvimento profundo com sua própria sociedade.

Em sua juventude, Benjamin escreveu um diálogo em que dois personagens, o Amigo e o Eu, discutem a religião frente ao colocar-se no mundo moderno. O personagem Eu afirma que o encontro com Deus inclui necessariamente que se encare o terrível: se Ele tudo criou, também criou o terror (uma ameaça constante na Alemanha da primeira metade do século XX em que viveu Walter Benjamin). Portanto, o mesmo Deus bondoso teria outra face, aquela que alimenta "nosso próprio ceticismo, em nossa própria desesperação" (BENJAMIN, 1993, p. 65). ${ }^{5}$ O desespero tem como consequência a fuga do indivíduo para dentro de si mesmo, onde a reflexão lhe permite confrontar, dessa feita, seu próprio terror: é isso que o induz, finalmente, a criticar o mundo.

A sociedade moderna seria, pois, a época da religiosidade entendida como espiritualidade dialética que se mostra "simultaneamente precursora e inimiga dos sentimentos religiosos" (p. 69). ${ }^{6}$ Desse modo, ela gera "a impaciência que salta por cima do abismo que ela mesma coloca a sua frente" (p. 70). ${ }^{7}$ Na presença da vertigem à beira do abismo, os sentimentos são paradoxais: ao mesmo tempo em que dá medo, o desafio do abissal fascina. São estes os afetos tão presentes numa sociedade hipócrita que renuncia à vida e promove sua autodestruição patológica. A religião moderna - da fé incontestada na ciência alçada ao posto de detentora da verdade - escraviza o homem e rouba sua força. No entanto, a mesma força que lhe é subtraída funda o desejo de uma sociedade mais humana. Quando a miséria provém da carência de espírito, o refúgio é o pudor do pathos reprimido e acovardado que preenche a atitude do individualista ao extremo, uma descrição do sujeito contemporâneo.

É o artista - esse ser despudorado e inconformado - quem pode expressar com sua arte os sintomas da nova religião. Com a expressão "nova religião" Benjamin expressa-se de novo dialeticamente: ela é tanto o capitalismo 
quanto uma sensação premente, "quase corporal" (p. 79) ${ }^{8}$ de busca da reflexão solitária. A única saída possível é fazer corresponder a moral individual a outra moralidade, a cultural, que garante o compromisso com o coletivo e suscita "o sentimento de algo novo e inédito pelo qual sofrer" (p. 80). ${ }^{9}$ É dessa maneira que o Deus profano do jovem Benjamin estabelece um balanço pendular entre o mundo e o eu mais íntimo.O movimento dialético desse pêndulo abre o pensamento para nele fecundar uma via de escape da alienação na individualidade egoísta. A profanação benjaminiana repousa no reconhecimento do compromisso moral do artista tanto quanto do pensador crítico com o que está fora dele, em sua necessária submissão ao mundo que assegura a distância de qualquer saber absoluto preconizado na ciência ou tradição religiosa. Tornase, então, urgente a construção de outro saber que nos permitirá observar o mundo com os mesmos olhos com que vasculhamos nossa própria alma.

Profanar também pode ser o ato de entregar uma figuração própria e única de Jesus ao coletivo do carnaval do qual se ausentam ostensivamente o Deus cristão mas também os orixás, que se recolhem a seus terreiros: as casas de santo mantêm, durante o evento, as portas fechadas. A arte do Cristo Mendigo afrontou a Igreja e autoridades civis e, em consequência, foi condenada por profanar os costumes cristãos. A Igreja, suspeitando do mau uso de seu panteão imagético no ambiente carnavalesco, abusou do poder institucional de representante de Deus no mundo dos homens: nesse momento, ela se esqueceu de que toda instituição é necessariamente humana, nunca divina.

É, contudo, exatamente nesse esquecimento que se revela seu caráter humano: a Cúria carioca censurou a alegoria sem a compaixão que o próprio Deus dispensaria a um pecador cristão. O resultado traduz o profundo sentido aristotélico da forma da arte que preenche o interior de seu invólucro material: o interdito tornou-se o curto-circuito de sentidos que a forma final do Cristo Mendigo instaurou no mundo e, mais especificamente, no mundo do samba.

Foi, por fim, com um gesto quase barroco que a Beija-Flor deu novo uso à alegoria interditada: ao cobri-la e afixar a faixa com os dizeres "Mesmo proibido, olhai por nós!" em vez de retirá-la do desfile, produziu uma obra com o qual se pode fazer história, se por história se entende, com Giorgio Agamben (2007), o ato de oferecer o poder que se supunha divino ao humano. Cabe, pois, ao pesquisador alegórico - se podemos assim nos expressar - assumir o compromisso com o coletivo na mesma medida em que se refugia na solidão do pensamento crítico a fim de decifrar suas próprias e mais íntimas alegorias, como Benjamin e Agamben propõem aos profanadores contemporâneos. 
Fechando a questão da autoria, uma lente de aumento focada no episódio do Cristo Mendigo poderia reparar num pequeno, mas importante, detalhe: se a autoria da ideia final da alegoria está em disputa, essa disputa é, no mínimo, falaciosa. Vejamos: Joãozinho Trinta criou para a representação alegórica uma cópia do Cristo Redentor coberto com trapos brancos e ditou, como carnavalesco, a última palavra sobre o que fazer com essa obra depois de proibida. Entretanto, quando foi informada da proibição, a comunidade BeijaFlor trabalhou unida e de imediato: no barracão, os operários carnavalescos procuravam uma saída para o enigma do que fazer com a alegoria; Anísio e Laíla correram para o barracão, cada um com sua ideia; e Joãozinho Trinta teve que decidir. Essa é, pois, uma história coletiva, do tipo que Agamben entende ser o requisito da profanação - ou da crítica - contemporânea e que está mais do que presente no carnaval e no desfile de cada uma das escolas de samba.

\section{CONCLUSÃO}

Este artigo partiu de uma das fontes mais reconhecidas da história da cultura cômica para, a seguir, retomar algumas análises favoráveis e contrárias ao conceito-chave de Bakhtin, o de "inversão social", a fim de traçar um breve diagnóstico da produção de pensamento sobre a crítica carnavalesca. Desse perfil, privilegiamos a contestação do paradigma bakhtiniano para alicerçar a relevância de os produtores do carnaval das escolas de samba serem tomados não como atores submissos ao poder do Estado, mas como agentes ativos e atuantes na construção e na atuação de suas agremiações e de seu próprio carnaval.

Por fim, nos dedicamos à análise da alegoria denominada Cristo Mendigo (Beija-Flor, 1989) no ambiente de crise da política da arte que encena sua proibição. Do fato empírico ressaltamos as figuras da Igreja censora, do carnavalesco criador e dos modos de protagonismo da escola de samba sobre sua própria produção para debater, em primeiro lugar, o enredo "Ratos e urubus, larguem a minha fantasia!" como documento de uma denúncia política intencional e que se tornou programática na obra posterior de seu carnavalesco. $\mathrm{E}$, depois, indagamos a legitimidade da noção de autoria da alegoria a partir do entendimento da escola de samba como lugar da produção de uma arte eminentemente coletiva.

Por fim, a esse texto só resta explicitar o desejo de que o campo investigativo das escolas de samba seja, cada vez mais, um lócus da cultura aberto às diferenças (BHABHA, 2001), assim como também um lugar de crise. Com crise queremos significar, sobretudo, uma espécie de território à espera 
dos objetos artísticos. É ali, nos limites do instituído e da lei, que eles constroem um ambiente propício à tarefa de confrontar sua sociedade, seu destino e seus próprios sentidos com confiança suficiente para entregar-se ao trânsito dialético da arte possível àqueles a quem ela foi sistematicamente negada na história.

\section{REFERÊNCIAS BIBLIOGRÁFICAS}

AGAMBEN, Giorgio. Profanações. Tradução e apresentação de Selvino Assmann. São Paulo: Boitempo, 2007.

AUGRAS, Monique. O Brasil do samba-enredo. Rio de Janeiro: Editora FGV, 1998.

BAKHTIN, Mikhail. A cultura popular na Idade Média e no Renascimento. $O$ contexto de François Rabelais. Tradução de Yara Frateschi Vieira. São Paulo: Annablume/Hucitec, 2002.

BHABHA, Homi K. O local da cultura. Tradução de Myriam Ávila, Eliana Lourenço de Lima Reis e Gláucia Renate Gonçalves. Belo Horizonte: UFMG, 2001.

BENJAMIN, Walter. Charles Baudelaire: um lírico no auge do capitalismo. (Obras escolhidas III). Tradução de José Carlos Martins Barbosa, Hermerson Alves Baptista. São Paulo: Brasiliense, 1989.

. La metafísica de la juventud. Tradução de Luis Martinez de Velasco. Barcelona/Buenos Aires/México: Paidós, 1993.

- Magia e técnica, arte e política. (Obras escolhidas I).

Tradução de Sergio Paulo Rouanet. São Paulo: Brasiliense, 1994.

. Imagens de pensamento. Tradução de João Barrento. Lisboa: Assírio \& Alvim, 2004.

. Origem do drama trágico alemão. Tradução de João Barrento. Lisboa: Assírio \& Alvim, 2004a.

- Passagens. Tradução de Irene Aron e Cleonice Paes Barreto Mourão. Belo Horizonte/São Paulo: Editora UFMG/Imprensa Oficial do Estado de São Paulo, 2007.

BERTHOLD, Margot. História mundial do teatro. Tradução de Maria Paula V. Zurawski, J. Guinsburg, Sérgio Coelho e Clóvis Garcia. São Paulo: Perspectiva, 2001.

BURKE, Peter. Cultura popular na Idade Moderna, na Europa, entre 1500 e 1800. Tradução de Denise Bottmann. São Paulo: Companhia das Letras, 1999.

CUNHA JR., Milton Reis. Paraísos e infernos. Na poética do enredo escrito de Joãozinho Trinta. Rio de Janeiro: Faculdade de Letras da UFRJ, 2006.

CUNHA, Maria Clementina Pereira. Ecos da folia. Uma história social do carnaval carioca entre 1880 e 1920. São Paulo: Companhia das Letras, 2001.

DA MATTA, Roberto. Carnavais, malandros e heróis. Para uma sociologia do dilema brasileiro. Rio de Janeiro: Zahar, 1979. 
DEBORD, Guy. A sociedade do espetáculo. Comentários sobre a sociedade do espetáculo. Tradução de Estela dos Santos Abreu. Rio de Janeiro: Contraponto, 1997.

EHRENREICH, Barbara. Dançando nas ruas. Uma história do êxtase coletivo. Tradução de Julián Fuks. Rio de Janeiro: Record, 2010.

FERREIRA, Felipe. Inventando carnavais: o surgimento do carnaval carioca no século XIX e outras questões carnavalescas. Rio de Janeiro: Editora UFRJ, 2005.

HAUSER, Arnold. Maneirismo. A crise da Renascença e o surgimento da arte moderna. Tradução de J. Guinsburg e Magda França. São Paulo: Perspectiva, 1993.

LÖWY, Michael. Walter Benjamin: aviso de incêndio. Uma leitura das teses Sobre o conceito de história. Tradução de Wanda Nogueira Caldeira Brant; tradução das Teses de Jeanne Marie Gagnebin e Marcos Lutz Muller. São Paulo: Boitempo, 2005.

MACEDO, José Rivair. Riso, cultura e sociedade na Idade Média. Porto Alegre/São Paulo: Ed. Universidade/UFRGS/Editora Unesp, 2000.

MEYERHOLD, Vsevolod. Meyerhold: textos teóricos. Traducciones de J. Delgado, R. Vicente, V. Cazcarra, J.L. Bello y José Fernandes. Madrid: Publicaciones de la Asociación de Directores de Escena de España, 1994.

MURICY, Kátia. Alegorias da dialética. Imagem e pensamento em Walter Benjamin. Rio de Janeiro: Relumé Dumará, 1999.

PERNIOLA, Mario. Pensando o ritual: sexualidade, morte, mundo. Tradução de Maria do Rosário Toschi, colaboração de Mariarosaria Fabris. São Paulo: Studio Nobel, 2000.

PETTA, Rosangela. Playboy entrevista Joãozinho Trinta. Playboy, São Paulo, ano XXIII, número 271, fevereiro de 1998, p.29-45.

QUEIROZ, Maria Isaura de. Carnaval brasileiro: o vivido e o mito. São Paulo: Brasiliense, 1992.

\section{NOTAS}

1 Essa é a data do primeiro desfile. Consagrada vice-campeã do Grupo 1 do concurso das escolas de samba, ela se apresentaria ainda uma segunda vez no Desfile das Campeãs, no sábado, 11 de fevereiro de 1989.

2 Em espanhol: "Es necesario hablar. No basta con limitarse a los ejemplos, sino que hay que hablar como se debe."

$3 \mathrm{Ou}$ "livro do drama de luto" que, muitas vezes é nomeado dessa forma, em alemão, pela teoria da arte que dele se utiliza. Esse é o livro em que Benjamin aprofunda um dos conceitos-chave de sua obra, o de "alegoria". 
4 Laila e a ideia do Cristo tapado - Beija Flor 1989, postado por jmrodriguezrodriguez em 10/10/2009, 8m30s. Disponível em http://www.youtube.com/ watch?v=wq6kNIbNX4A.

5 Em espanhol: "en nuestro própio escepticismo, en nuestra propia desesperación.."

6 Em espanhol: "es, a la vez, precursora y enemiga de los sentimientos religiosos."

7 Em espanhol: "Ia impaciencia salta por encima del abismo que ella misma pode por delante."

8 Em espanhol: "casi corporal".

9 Em espanhol: "lo más concreto es el sentimiento de algo nuevo e inaudito por lo que sufrir."

Fátima Costa de Lima é professora e pesquisadora do Departamento de Artes Cênicas do Centro de Artes (Ceart) da Universidade do Estado de Santa Catarina (Udesc), mestre em sociedade e cultura pela Udesc e doutora em história cultural pela UFSC, com a tese Alegoria benjaminiana e alegorias proibidas no sambódromo carioca: o Cristo Mendigo e a carnavalíssima trindade

Bruno Filippo é professor das Faculdades Integradas Hélio Alonso (FACHA), da Universidade Estácio de Sá (UNESA) e coordenador da Escola de Arte Cultura e Eventos (EACE). 